\title{
Modernism in Indian Poetry: "at the time, we didn't dissociate between East and West, it was just part of Bombay"
}

\section{Laetitia Zecchini}

\section{(2) OpenEdition Journals}

Electronic version

URL: https://journals.openedition.org/ces/7859

DOI: $10.4000 /$ ces.7859

ISSN: 2534-6695

\section{Publisher}

SEPC (Société d'études des pays du Commonwealth)

\section{Printed version}

Date of publication: 1 September 2011

Number of pages: 33-42

ISSN: 2270-0633

\section{Electronic reference}

Laetitia Zecchini, "Modernism in Indian Poetry: "at the time, we didn't dissociate between East and West, it was just part of Bombay"', Commonwealth Essays and Studies [Online], 34.1 | 2011, Online since 16 November 2021, connection on 01 December 2021. URL: http://journals.openedition.org/ces/7859 ; DOI: https://doi.org/10.4000/ces.7859

\section{(c) $(1) \&$}

Commonwealth Essays and Studies is licensed under a Licence Creative Commons Attribution - Pas d'Utilisation Commerciale - Pas de Modification 4.0 International. 


\section{Modernism in Indian Poetry: "at the time, we didn't dissociate between East and West, it was just part of Bombay"}

The emergence of modernism in India in the 1950s and $1960 \mathrm{~s}$ was a time of experimentalism for Bombay poets. The hybrid transactions that took place between translation and creative writing, between English and other Indian languages, not only expose the simultaneous confluence of local and world literature, but also propose a form of belonging as a "defiant all-inclusive category" (Kolatkar), an open-ended process of translation where origins become irrelevant.

The contemporary Indian poets on whom this paper will focus are not diasporic poets published abroad but live or have lived almost all their life in India, sometimes in a single place, and hence may seem to be, in a sense, stubbornly "local" poets. Modernism has often been viewed, in turn, as a Euro-American product, transnational only insofar as many modernist artists and writers were expatriates or exiles in Europe and in the United States. But it is time to "clear a space" (Chaudhuri, Clearing a Space) for alternative trajectories and genealogies of modernism outside of these Western filiations, beyond the canonical period of high modernism (1910-1930), ${ }^{1}$ and to explore how modernism was reinvented through displacement. For modernism can be seen as a diasporic and travelling paradigm, in the sense James Clifford rethinks of culture as travel and practices of displacement constitutive of cultural meanings. Indian poetic modernism precisely represents the creative offspring of multiple lineages, East-West transactions, translations and decontextualizations, the product of a constellation of languages and traditions which blur the borders between the local and the global.

I must confess I had to overcome an initial reticence regarding the designation of the panel in which this paper was presented ("Tectonic plates: the local and the global") which seemed at first glance to imply only confrontation and collision rather than the form of dialogic interactions (where national origins may become irrelevant) which have fashioned Indian poetry and modern creativity. Yet, recognizing the traffics and reciprocal exchanges between irreducibly plural and permeable cultures does not mean overlooking the formidable, unresolved and sometimes "unhealable" tension which is also at stake. The words included in the title of my paper ("at the time we didn't dissociate between East and West") are actually those of the poet Adil Jussawalla when asked if modernism in India during the 1950s and 1960s was exclusively associated with the West and hence experienced as imitative. ${ }^{2}$ Though this awakening to modernism came partly through Western sources, he did hope like many other Indian artists at the time that he was not writing like his English or American counterparts. To him, it is today that the issue has become contentious: "at the time if we saw Macbeth in an abstract setting and avant-garde direction, for us it was simply

1. For this reason, "modernism" is spelt without a capital.

2. Private conversation, Mumbai, 16 November 2010. 
modern art [...], we didn't dissociate between East and West. It was just part of Bombay."

So what does this statement tell us about the context in which modernism both in the visual arts and in literature emerged in India? How was modernism, in India, crucially shaped by the metropolis, like elsewhere in the world? What, precisely, was Bombay like from the 1950s up to the 1970s? In what way was this "local" scene connected to a certain kind of cosmopolitanism? How does contemporary Indian poetry - while signaling alternative cartographies and lineages of modernism - reflect these cosmopolitan transactions and local reinventions of circulating transnational paradigms?

Let us start by deconstructing the facile binaries which may exist between the local and the global, and which partly intersect with the dichotomy between differentialism and universalism. Sheldon Pollock claims it is necessary to go beyond the desperate alternative "between, on the one hand, a national vernacularity dressed in the frayed period costume of violent revanchism and bent on preserving difference at all costs and, on the other, a clear-cutting multinational cosmopolitanism that is bent, at all costs, on eliminating it" (17). Numerous contemporary cultural theorists have shown that the global does not systematically oppose the local, that the global is not always imperial or homogenizing, threatening an "authentic" pristine and unadulterated local culture, that, to quote Arjun Appadurai and Carol Breckenridge in the first chapter of Consuming Modernity, globalized modernity does not necessarily seduce the world into sameness (Breckenridge 1). Locality, conversely, must not be reduced to parochialism. The relations between the global and the local can be more productively seen as varied relations of enmeshments, interactions, negotiations and appropriations, however challenging.

James Clifford argues that it is necessary to look at culture in terms of travel relations and to question the organic, naturalizing bias of the term "culture" seen as a rooted body that grows, lives and dies (17-45). The "border," the "boundary" "from which something begins its presencing," to quote Homi Bhabha drawing on Heidegger (7), or the threshold could become, in a globalized and increasingly interconnected world, the paradigmatic figure of culture. The relevant question would therefore not so much be "where are you from?" but rather "where are you between?" (Clifford 37). And it is this liminal interstitial paradigm of "in-betweenness," one of the most potent tropes of postcolonialism, which subverts fixed identities and locations and signals both a "beyond" and an itinerary that seems the locus of contemporary Indian poetry and Indian modernism.

With the paperback revolution in the publishing industry after the Second World War in India that coincided with a "feverish activity in translation" and "unleashed a tremendous variety of cross-influences almost all of a sudden," writes the bilingual Marathi-English poet Dilip Chitre, the 1950 s and 1960 s represented a "fantastic conglomeration of clashing realities" (Anthology 5) that was particularly palpable in Bombay: city of gold by the early $20^{\text {th }}$ century and magnetizing city for migrants, gateway for India and window on the West, "dream city of cosmopolitan desire" (Prakash 75) and unlimited possibilities, mosaic of modern culture and communal mix. 
In India, cosmopolitan colonial cities like Bombay or Calcutta constitute the interface between the local and the global. In his seminal book The Triumph of Modernism: Indian Artists and the Avant-garde, the art historian Partha Mitter proposes the concept of "virtual cosmopolis" to explain the critical engagement of the urban intelligentsia with modernity in colonial cities where these interactions were largely negotiated through the printed medium but also through English, the global language as it were (11). Mass migration is obviously another factor that shapes cultural globalization. If metropolises constitute the interface between the local and the global and represent places of formidable tension and contiguities, it is also because they are peopled by migrants and diasporic minorities who represent "the most tangible and proximate presence of the global or transnational world as it exists within 'national' societies" (Bhabha xxii). Migrants also negotiate between plural belongings and cultural traditions, without taking root in a single identity, while forging transnational affiliations across the global/local divide.

Bombay was precisely such a place of cosmopolitanism. It was indeed primarily forged through the printed medium since after the Second World War, books from all over the world literally started pouring onto the pavements, through English, which acted as a window to global literatures and international modernism, but also through migration and interaction with people from all origins, languages, and cultures. "Mumbai (then still Bombay for English speakers) liberated us," writes the poet Dilip Chitre about himself and the other Marathi-English poet Arun Kolatkar ("Remembering Arun Kolatkar"), while also declaring that both their works were rooted in the "maddening cosmopolitan mix of Mumbai" ("Street Fight Poet").

Bombay is certainly the most composite, multilingual and multiconfessional of Indian cities, where Portuguese, British, Jews, Parsis, Iraqis, Russians, Chinese, Persians but also Indians and refugees from the whole sub-continent congregated and left their mark. "Most "Bombay" poets are not originally from the city and have precisely migrated there, uprooted from other states, small cities or rural backgrounds (Dilip Chitre came from Gujarat, Arun Kolatkar from Kolhapur, a small town in South Maharashtra, etc.). When they were born or brought up in Bombay, they often come from religious minorities who, at one point in time, also found refuge in the city, like Adil Jussawalla and Gieve Patel who are Parsi or Nissim Ezekiel who was Jewish. During the 1940s and 1950s, the city also represented a kind of haven for European war émigrés who often played a seminal role, especially in the visual arts, in mediating international avant-garde and fostering modernism. The Progressive Artists' Group which is the most influential school of modern art in India and was formed in 1947 in Bombay is precisely a product of such migrations and cosmopolitanism. Not only were Jewish European émigrés largely involved in the development of the Progressive Artists' Group (like the German cartoonist Rudi Von Leyden or the Austrian painter

3. Gyan Prakash talks about the dazzlingly diverse population of a city that held the promise of "exciting newness and unlimited possibilities" (5) and writes: "Attracted by the city's position as the hub of manufacturing, finance, trade, advertising, media, and the film industry, people from all over India have washed up on the island. They speak different languages - Marathi, Gujarati, Hindi, Urdu, Bengali, Tamil, Malayalam, English - and practice different faiths - Hinduism, Islam, Christianity, Zoroastrianism, Jainism, Judaism. [...] Mumbai's map is a jigsaw puzzle of distinct neighborhoods marked by community, language, religion, dress and cuisine" (11). And Arun Kolatkar, in the unpublished book proposal in English entitled Balwant bua, writes of the "thick, multiracial, multicultural, and multilingual soup" of Bombay inner city (Kolatkar Papers). 
Walter Langhammer who became the first arts director of the Times of India), but the founding fathers of this group all come from different regional, religious and linguistic backgrounds: F. N. Souza from Goa, K. H. Ara from Hyderabad, M. F. Husain from Pandharpur in Maharashtra, S. H. Raza from Madhya Pradesh, Sadanand Bakre from Baroda, etc.

When many modern Indian poets started writing in the 1950s and 1960s, it was the time for Beat poetry, sound poetry, visual poetry, concrete poetry, jazz poetry and continuing surrealism; a time of openness to everything else that was happening in the world and of feverish experimentation with all kinds of forms and mediums. Bombay poets engaged with these new paradigms and with the internationalism of the avantgarde. They had all been exposed to the "modernist" galaxy and often consciously placed themselves in this lineage. An unpublished fragment by Arun Kolatkar reads as follows: "I was born the year Hart Crane killed himself / Nine years after Ulysses was burnt / three years after Auden published his first collection / one year after Maikovsky killed himself / I had my first tooth when / Dylan Thomas published his first collection" (Kolatkar Papers).

Bombay poets hence developed strong affinities with European modernism and the counter-culture of the 1960s. Ezra Pound and T. S. Eliot, the Dadaists and surrealists, William Carlos Williams and the contemporary Beats in the United States, but also anti-establishment little magazines like Partisan Review, Paris Review or Evergreen Review, which were read, circulated and discussed, are the defining influences of a lot of modern Indian poems.

The need to "make it new" was certainly felt outside of Europe and the United States. Schools of "new poetry" which could be the equivalent of "modernism" in India emerged in major Indian languages ("Nayii kavitaa" in Hindi, "nava kavya" in Marathi, etc.). After the historical rupture and fundamental cultural break of colonization, the imposed canons had to be challenged: British norms with the midVictorian romantic literary ideals (and its literary icons like Keats, Shelley or Wordsworth) introduced by Macaulay's system of education, but also the pan-Indian specific trend of highly subjective and emotional literature in the 1920s (known as chaayaavaad), often imitative of Romantic British poetry with its elegant, abstract and elusive language. The almost exclusive priority (largely dependent on the colonial definition of what a literature, a culture or a tradition is supposed to be) given to textual literatures, to the Sanskritic and Brahmanical traditions at the expense of the oral and syncretic, the vernacular and contemporary also came increasingly to be questioned. Modernism became a paradigm for emancipation, a counter-romantic breaking away from representational art and Western rationality but also ornate style and rhetoric, elusive and symbolic language, in order to foreground mundane realities, everyday language and the speaking voice. "Today we paint with absolute freedom of content and techniques almost anarchic," wrote the painter F. N. Souza in 1949 (Dalmia 43) - a credo that, providing you change "paint" to "write," was shared by most Indian writers at the time.

4. Allen Ginsberg and Peter Orlovsky met many Indian intellectuals and writers during their 1962-1963 trip to India and while in Bombay, befriended Arun Kolatkar (whose translation of Ginsberg's Kaddish into Marathi appeared in a little magazine in 1963) and other poets. 
This period which is sometimes described as a kind of "Indian renaissance" signaled years of collective endeavors. The poets often formed small alternative presses and workshops, countless journals and underground anti-establishment "little magazines," like the cyclostyled Shabda (literally "word" or "speech") in Marathi started by Dilip Chitre, Arun Kolatkar and others in 1954 or Damn You: A Magazine of the Arts, started in 1965 by the poet Arvind Krishna Mehrotra and modeled on the American publication Fuck You: A Magazine of the Arts, which "rapidly became a temporary outpost of the American and European avant-garde" (King 23). ${ }^{5}$ This renaissance affected all artistic domains. We thus find in the 1950s and 1960s in Bombay the same creative symbiosis between the visual arts and literature that is a trademark of Euro-American modernism. Amit Chaudhuri talks about the "metropolitan flirtations between artistic subcultures" and the way Bombay poetcritics like Nissim Ezekiel, Arvind Krishna Mehrotra, Adil Jussawalla and Gieve Patel "poached and encroached upon the territory of painters" (Clearing a Space 224). Many of the journals and little magazines published at the time are meticulously crafted and designed works of art, edited together by painters and poets (V rischtik edited by the painters Gulam Sheikh and Bhupen Khakar, Shabda edited by the painter Bandu Waze, by Dilip Chitre, Arun Kolatkar and others) who not only worked together but sometimes, like Gieve Patel or Kolatkar who trained as a visual artist at the J. J. School of Art, were both painters and poets. Kolatkar thus designed the covers for a lot of little magazines and collections: Shabda in the 1950s, Dionysus in the 1960s, all the covers of the small publishing cooperative Clearing House later in the 1970s, etc.

Poets, writers, painters, theater and film directors gathered around the J. J. School of Art which became "the nucleus for all art activity" (Dalmia 4) on India's West coast but also around the Jehangir Art Gallery in the South Bombay district of Kala Ghoda, where the Progressive Artists' Group was formed, notably in the Artists' Aid Fund Center which Dilip Chitre evokes as follows: "the place reminded me more of an orphanage than an art gallery" ("Remembering Arun Kolatkar"). They often lodged together in small congested spaces and lived in "self-conscious literary bohemianism" (Engblom 391).

Just like there had been an American scene of sorts shaped by the poet William Carlos Williams and certainly a Paris scene in the 1920s, the emergence of a Bombay "scene" from the 1950s onwards for poetry (since poets were often publishers, editors, anthologists, designers, sponsors, the distributors and critics of their own books) and for modernism is unquestionable. Anjum Hasan considers Bombay at the time "not just as a place where the poetry was written but as a place that, uniquely, made the writing of this poetry possible" (66). And it is a modernism that revises the mutually exclusive local and global, Eastern and Western paradigms, as Sneharika Roy has precisely pointed in her own article in this issue. Partha Mitter is thus absolutely right in contesting the "Picasso manque" syndrome (7), the idea that modernism in India or other countries outside of the Euro-American axis is only "derivative," parasitic or "belated." The flexible syntax of modernism (whose point of departure

5. Anjum Hasan suggests a scene charged with energy and risk-taking, but also writes about the transient character of a lot of these Bombay magazines, with, she claims, "names no one remembers today": Bombay Duck, Opinion, Dionysius, Blunt, Indian Writing Today, Tornado, Opinion Literary Quarterly, Volume, Fulcrum, Keynote, Kaiser-e-Hind, The Bombay Literary Review, and so on (65). 
has often been considered European ${ }^{6}$ ) is reinvented through displacement and decontextualization. It gets globalized and is then adopted, adapted and transmuted (or cannibalized) to suit local needs and become a means of self-expression. It is thus irrelevant, once the uprooting, détour or displacement of a paradigm has taken place, to define it according to so-called national "roots." Origins are replaced by itineraries.

Though totally steeped in Western and European literature, poets also outgrow Western modernism or rather relate and relocate it dialogically with the recovery of a "native modernity." This is notably the case with the rediscovery and remaking of bhakti, a medieval movement of personal and popular devotion and "revolutionary form of Hinduism" (Ramanujan 26) which opposed Brahmin orthodoxy and religious monopoly, rejected Sanskrit to produce extraordinary poetry in the vernaculars. Indian poetic modernism, by claiming both the lineage of the Euro-American avant-garde but also of pre-colonial Indian traditions, exposes the simultaneous confluence of local and global paradigms, of hybrid transactions between English and other Indian languages. Arvind Krishna Mehrotra remembers that at the end of the 1960s he was "writing under Breton's influence one week and under Ginsberg's the next" (de Souza 105), while at the same time trying his hand at translating the $15^{\text {th }}$-century Hindustani bhakti poet Kabir. Around the same time Dilip Chitre was translating Mallarmé and Rimbaud into Marathi and Tukaram into English, and Arun Kolatkar was both steeped in the 17th-century marathi bhakti poet Tukaram while avidly discovering and reading Dylan Thomas, Pablo Neruda, Apollinaire, E. E. Cummings, Samuel Beckett, William Carlos Williams, and many others. As the writer and critic Amit Chaudhuri has so eloquently argued in his lastest book of essays, Indian modernity is a space of ambivalence and traction, characterized by the constant tension between disownment and recovery, disruption and return, exile and homecoming or, to use Glissant's terms, diversion and reversion. Chaudhuri thus identifies a "secular Indian sensibility, to which the rejection of Indigenous culture and religion, relegating them to the realm of superstition and irrationality, would be an important act on the one hand; as would, on the other, its recovery of that very culture as a life-giving, if perennially problematic part of itself' (Chaudhuri, Clearing a Space 41). The recovery of bhakti by Indian poets and its recasting today seems to me precisely a life-giving, more precisely form-giving reinvention of the self.

These transactions are forcefully expressed in the translation practice of modern Indian poets, who have been translating bhakti texts from Hindi, Marathi and other vernaculars into English for the past fifty years. It is important to bear in mind that modern poets fashion their voice at a time when, after the colonial encounter and the advent of modernity, many writers, whatever the language they write in, and in spite of the excitement of the period in which these poets start writing, acknowledge a form of

6. Taking the cue from Dipesh Chakrabarty, it is however necessary to give up such a developmental and historicist perspective (the "first in the West, and then elsewhere" paradigm). Who came first? Who imitates whom? These questions are not only irrelevant but incidentally far more intricate than may seem at first glance, once we remember that Western modernism, especially in the visual arts, has been sustained by so-called "primitive" art, by African, Oceanic and Japanese forms.

7. "Détour" as defined by Édouard Glissant in the sense of "diversion." Glissant opposes it to the impulse of "return" (reversion) which he describes as follows: "the obsession of a single origin. One must not alter the absolute state of being. To revert is to consecrate permanence, to negate contact" (Carribean Discourse 16). This statement is qualified later when he shows that diversion and reversion in fact go hand in hand, if we understand reversion not as a "return to some immutable state of being, but a return to the point of entanglement" (26). 
intimate dislocation between adversarial belongings: between English and the vernaculars, oral and textual traditions, high and low culture, writers and their audience, the westernized literate elites to which numerous Indian poets belong and the common man of the Indian "masses" whom they want to address. What is interesting here is that the tension between local and cosmopolitan systems, between languages, temporalities or affiliations, between the spoken word and the written word, is in a sense negotiated through the practice and byphen of translation. "Translation then participates in our dream of making out of a historical past a contemporary past, creating of the so-called linear sequential order of history a simultaneous order, an active presence," writes A. K. Ramanujan (189). This is perhaps all the more vital for Indian poetry in English as it has often been criticized for being deracinated and alien, and for using a global "inauthentic" language that is not "organically" and "naturally" rooted in the Indian soil and the Indian past.

"The return to the deeper and larger tradition, combined with the immediate heritage of Western poetry, and the spirit of restless individual experiment, resulted in a remaking of the tradition itself," writes the poet Dilip Chitre (An Anthology of Marathi Poetry 4). And this "remaking" (not restoration) concerns both the medieval bhakti tradition and the modernist tradition. For in the same way "Western" modernism has been estranged and transmuted in and through India, what "was" or "used to be" has been displaced, pluralized and recreated. Bhakti tradition must be reinvented from a distance, after a historical rupture, in a different language (like English), which also implies a confrontation with otherness (like Euro-American modernism) and prevents attempts to restore a pedigree. This recovery, performed through translation, never takes the guise of a nativist return to oneself. Contemporary poets prove that there is no such thing as an innate and organic relationship to tradition. Original, God-given, national or "natural" filiations must be converted into historical affiliations, into connections that you make and invent rather than inherit (Said 23).

This reinvention blurs the frontier between what is "native" and "alien," "Indian" and "Western," "modern" and "traditional," "regional" and "cosmopolitan." As a result, Arun Kolatkar's and Arvind Krishna Mehrotra's translations of, respectively, $17^{\text {th }}$-century Tukaram and $15^{\text {th }}$-century Kabir, not only offer contemporary performances or retellings of the bhakti families of texts, but they also conflate traditions. By using anti-style colloquial simplicity and slang, by mixing the metaphysical with the everyday, shedding superfluous words, ornate syntax and punctuation, these translations are as much indebted to a modernist aesthetics (since modernist poets tried to create an idiom of "local particulars," close to the spoken language but also concrete, concise and economical) as to bhakti poetics, to Ezra Pound, E. E. Cummings, and William Carlos Williams as to Tukaram or Namdev.

The restaging of medieval Indian bhakti is often made in a kind of jazzy, Ginsbergian "americanese” which is akin, especially in Kolatkar's work, to the blues, rock and folk lyrics which fascinated him. Blues, bhakti and folk are "collective traditions" that have evolved through oral transmission and improvisation, through the rugged and robust voices of poet-singers who constantly rework a pre-existing material. Kolatkar, like other Indian poets (Arvind Krishna Mehrotra and Adil Jussawalla for example) saw himself much more as a craftsman or a bard than as a trained virtuoso. The absence of boundary between songs and poems (Bhakti 
compositions were originally songs) and the strong influence of blues and black American folk-composers, of Bob Dylan and Joan Baez in the heyday of American folk music revival, connect all these inheritances.

"I want to reclaim everything I consider my tradition" (italics mine) writes Kolatkar (de Souza 19), also asking for the right "to claim everything that comes from our roots and everything that comes from elsewhere and put the two together in one defiant all-inclusive category" ("No Easy Answers"). Through this affiliating process, poets choose their neighbors and their ancestors. In a newspaper article published in the 1990s, Adil Jussawalla argues that his literary neighbours are not necessarily those who belong to the same national or linguistic community. He also demonstrates the power of translations to blur the local v. global dichotomies. Neither distance nor language have ever defined our neighborhood, writes Adil Jussawalla, offering the example of the English-Marathi poet Dilip Chitre whose translations from Marathi into English of the medieval bhakti poet Tukaram have reached both Iowa and Tokyo. Some readers have thus chosen to see Dilip Chitre as neighbor and Tukaram as ancestor in the United States and in Japan (Jussawala 5).

Dilip Chitre's articles have often dwelt upon the power of translations to mediate between different selves, between the "East" and the "West" (though categories as monolithic as these do seem quite useless), between different languages and temporalities:

I read Tukaram in depth while reading modern and contemporary literature in the original or in translation. My excitement deepened when I began to see in Tukaram an unsuspected contemporary [...]. At times, while reading Nietzsche or Kierkegaard or Heidegger I would recall Tukaram. At other times, I would discover that I was able to understand better Meister Eckhart, Juan de la Cruz or William Blake because I had been exposed to Tukaram. (Says Tuka 306)

And again, "if you look at my long poems in English you will find meditative passages the tone of which belongs to a different tradition. My English poems have been influenced by Marathi tradition. I became a Marathi poet using an Anglo-Saxon instrument" (Ramakrishnan 235). This last statement also shows that bilingual poets like Dilip Chitre or Arun Kolatkar, who write in an alleged "local" language like Marathi and a so-called "global" language like English, blur the equation between language and nation. They claim that there is no national property of identity and language, that you can be a Marathi poet (and even a bhakti poet) while writing in English, and belong to what has been reductively identified as "Euro-American" modernism while writing in Marathi.

They also demonstrate that if "to a poem, the location - whether cultural, geographical or fictive - is everything" (Mehrotra in Chaudhuri, Modern Indian Literature 464), you can be rooted in a location and open it to a rhizome-like network of connections with other locales, cultures and languages. Place is both indispensable and "exceedable." Arun Kolatkar, for instance, lived most of his adult life in a oneroom apartment with his wife in Bombay. He very seldom travelled and his routine, which was mostly centered around the South Bombay Kala Ghoda neighborhood, remained virtually the same for the last thirty years of his life. Yet he made the whole world converge to him. Like Walter Benjamin, he was afflicted by a form of bibliomania, reading across disciplines, genres, epochs and languages, collecting 
thousands of books which, for lack of space, he would disseminate across Bombay and ask his friends to store for him: chronicles of the crusades, travel writing and memoirs, books on magic, religion, witchcraft, bread-making, papermaking and history, forgotten arts and crafts and medieval households, sexual life and everyday life in different parts of the world, Heloise and Abelard, Rebecca West and Ossip Mandelstam, countless dictionaries, grammars and methods for learning languages (Kannada, Persian, Arabic, Sanskrit, Old Marathi, Serbo-croatian), etc. ${ }^{8}$

The world was his heritage. Nothing illustrates this more than a passage from an interview conducted in the early 1970s and published in a Marathi little magazine. When Kolatkar was asked which poets had influenced him, he responded in a somewhat exasperated tone:

Want me to give you a list? Whitman, Mardhekar, Manmohan, Eliot, Pound, Auden, Hart Crane, Dylan Thomas, Kafka, Baudelaire, Heine, Catullus, Villon, Dyaneshwar, Namdev, Janabai, Eknath, Tukaram, Wang Wei, Tu Fu, Han Shan, Ramjoshi, Honaji, Mandelstam, Dostoevsky, Gogol, Isaac Bashevis Singer, Babel, Apollinaire, Breton, Brecht, Neruda, Ginsberg, Barthes, Duras, Joseph Heller, Enzensberger, Gunter Grass, Norman Mailer, Henry Miller, Nabokov, Namdev Dhasal, Patte Bapurav, Rabelais, Apuleius, Rex Stout, Agatha Christie, Robert Shakley, Harlan Ellison, Bhalchandra Nemade, Durrenmatt, Aarp, Cummings, Lewis Carroll, John Lennon, Bob Dylan, Sylvia Plath, Ted Hughes, Godse Bhatji, Morgenstern, Chakradhar, Gerard Manley Hopkins, Balwantbua, Kierkegaard, Lenny Bruce, Bahinabai Chaudhari, Kabir, Robert Johnson, Muddy Waters, Leadbelly, Howlin' Wolf, John Lee Hooker, Leiber and Stouller, Eisenstein, Truffaut, Woody Guthrie, Laurel and Hardy. (Engblom 399)

Kolatkar, along with other Indian writers of his generation, by locating his modernity in the most immediate present of world literature, but also in a pre-colonial past, invents a distinct voice for modernism. These poets also demonstrate that globalization or creolization, to quote Édouard Glissant, can be something else than dilution, fusion or evaporation into some kind of undifferentiating magma, but the concrete and poetic instauration of the relation between the place where you are, from which you speak, and all other possible places: "Literature does not spring from a suspension [...]. It originates in a particular place. The place from which a literary work emanates is inescapable, but today the literary work is all the more relevant to a specific location that it relates it to the "whole-world'."'

Laetitia ZECCHINI, CNRS - ARIAS

\section{Works Cited}

BHABHA, Homi. The Location of Culture. 1994. New preface by the author. New York: Routledge Classics, 2010.

Breckenridge, Carol A., et al., eds. Consuming Modernity, Public Culture in a South Asian World. Minneapolis: U of Minnesota P, 1995.

Chaudhuri, Amit. Clearing a Space, Reflections on India, Literature and Culture. New Delhi: Permanent Black, 2008.

CHAudHURI, Amit., ed. The Picador Book of Modern Indian Literature. London: Macmillan, 2001.

8. Part of Kolatkar's monumental library which I was able to consult in January 2011 is today stored at the Bhandarkar Oriental Institute in Pune (Maharashtra).

9. "La littérature ne se produit pas dans une suspension. [...] Elle provient d'un lieu, il y a un lieu incontournable de l'émission de l'œuvre littéraire mais aujourd'hui, l'œuvre littéraire convient d'autant mieux au lieu, qu'elle établit relation entre ce lieu et la totalité-monde." (Glissant, Introduction 34) 
CHITRE, Dilip, ed. An Anthology of Marathi Poetry (1945-1965). Bombay: Nirmala Sadanand, 1967.

CHITRE, Dilip. "Remembering Arun Kolatkar." 5 December 2010 $<$ http://dilipchitre.spaces.live.com>.

Chitre, Dilip, trans. Says Tuka, Selected Poems of Tukaram. New Delhi: Penguin, 1991.

Chitre, Dilip. "Street Fight Poet." Tehelka 2 (June 2007). 7 December 2010 $<$ http://www.tehelka.com/story_main30.asp?filename=hub020607Street_fight.asp>.

CLIFFORD, James. Routes: Travel and Translation in the Late Twentieth Century. Cambridge, MA: Harvard UP, 1997.

DalmiA, Yashodhara. The Making of Modern Indian Art: The Progressives. New Delhi: Oxford UP, 2001.

De Souza, Eunice. Talking Poems, Conversations with Poets. New Delhi: Oxford UP, 1999.

ENGBlom, Philip. "Arun Kolatkar: Reading Jejuri and Aruna Kolatakaracya Kavita in Tandem." New Quest: An Interdisciplinary Journal of Society and Culture 146 (2001): 389-440.

Glissant, Édouard. Caribbean Discourse. 1981. Trans. J. Michael Dash. Charlottesville: U of Virginia P, 1989 .

-. Introduction à une poétique du divers. Paris: Gallimard, 1996.

Hasan, Anjum. "Your Missing Person', Clearing House and the Bombay poets, The forgotten story of a poetry publishing collective." The Caravan 2.11 (November 2010): 62-9.

Jussawalla, Adil. "Who is My Neighbour?" The Sunday Times of India [n. d.] 1994: 5.

KING, Bruce. Modern Indian Poetry in English. Revised ed. New Delhi: Oxford UP, 2001.

KolatKar, Arun. "No Easy Answers." The Hindu Literary Review 5 (September 2004). 7 June 2011 $<$ http://www.hindu.com/lr/2004/09/05/stories/2004090500110100.html>.

—. Collected Poems in English. Ed. Arvind Krishna Mehrotra. Northumberland: Bloodaxe, 2010.

- Kolatkar Papers, unpublished private archives, Bombay.

Menrotra, Arvind Krishna, trans. Songs of Kabir. New York: New York Review of Books Classics, 2011.

MitTeR, Partha. The Triumph of Modernism: Indian Artists and the Avant-garde, 1922-1947. London: Reaktion, 2007.

POLLOCK, Sheldon. "Cosmopolitan and Vernacular in History." Cosmopolitanism. Ed. Carol. A. Breckenridge, Sheldon Pollock, Homi Bhabha, and Dipesh Chakrabarty. Durham: Duke UP, 2002. 15-53.

PrakASH, Gyan. Mumbai Fables. Princeton: Princeton UP, 2010.

Ramanujan, A. K. The Collected Essays of $A$. K. Ramanujan. Ed. Vinay Dharwadker. Delhi: Oxford UP, 1999.

RAmakrishnan, E. V. "Poetry Is Language Looking at Experience. A Conversation with Dilip Chitre." Making it New: Modernism in Malayalam, Marathi, Hindi Poetry. Shimla: Indian Institute of Advanced Study, 1995. 228-37.

SAID, Edward. The World, the Text and The Critic. Cambridge, MA: Harvard UP, 1983.

TRIVEDI, Harish. Colonial Transactions: English Literature and India. Calcutta: Papyrus, 1993. 